entregarse al pesimismo y decretar que no queda nada que hacer. Miramos el tablero de ajedrez y comprendemos que podemos ganar aún la partida, a condición de jugar bien. Hay que afrontar el peligro con una conciencia solidaria. Sólo puede tener acción suficiente para detener o equilibrar la influencia que pesa sobre nosotros, un concierto de todas las repúblicas latino americanas realizado alrededor de un contra postulado defensivo. Es la obra de hombres nuevos en una América regenerada.

Tan bien hecho estaba el nudo que ataba la lanza al carro de Gordio, el viejo rey de Frigia, que nadie lograba descubrir los cabos. El oráculo había prometido el imperio a quien lo deshiciera. Pero era tan hábil el enredo, tenía tantas vueltas y revueltas, que no asomaba nunca principio ni fin. La Doctrina de Monroe, más que un enigma, es un nudo gordiano. En vano ensayan los políticos de nuestra América su ciencia y su paciencia. Siempre naufragan en insalvables dificultades. Pero esto no implica que el nudo no se pueda desatar. Yo no digo que imitemos el gesto de Alejandro. La diplomacia por renovadora que sea, tiene formas más suaves de expresión. Pero no cabe duda de que habrá que encararse con el obstáculo empleando sistemas adecuados a la magnitud del problema. No para conquistar, esta vez, el imperio, sino para detener su marcha.-M A N U E L U G A R T E.

Exclusivo para Atenea en Chile

\title{
Sentido plástico de nuestra cultura
}

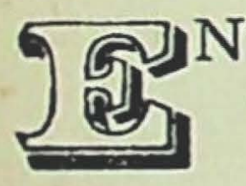

NTODOS los aspectos de la cultura y del progreso de nuestra época se advierte una pasión irreprimida por la forma y el color. Así es como el hombre contemporáneo busca la satisfacción de sus necesidades, cada vez más complejas, en la producción de una industria con apariencia artística. Ahí están el arte exclusivo y hechizado del letrero luminoso, el clarobscuro centelleante del cinematógrafo, la mistica suntuosidad de las vidrieras comerciales, los caprichos estilizados de las indumentarias, las severas y flamantes creaciones de la ebanistería y el vasto prodigio del arte aplicado en general.

Margen habría para hacer un nutrido ensayo sobre la trascendencia social y psicológica de esta franca hiperestesia del sentido plástico. No otra cosa que la expresión de una libido 
videnti constituye, por ejemplo, la enorme afición de la gente al espectáculo de bataclán, al cinematógrafo; el creciente culto por el deporte y la tendencia a aligerar el vestido o a ceñirlo al cuerpo, de manera que se luzca en plenitud la realidad y pureza de las formas. El deporte turístico, desarrollado intensamente gracias a la invención de portentosas máquinas, es lo que mejor informa, en nuestra época, el predominio del sentido visual sobre los demás sentidos. Trasladarse rápidamente de un punto a otro; ver, en el menor tiempo que sea dado, la mayor cantidad de imágenes sensibles, he ahí el ideal de la civilización nerviosa y panorámica que es la nuestra.

Si hubiéramos de buscar el antecedente histórico de esta tendencia al "visualismo», tendríamos que referirnos tal vez a la escuela filosófica de Comte. Surgido como una reacción a las truculencias metafísicas de los escolásticos, el positivismo descartó de la filosofía toda proposición que no estuviese basada en la experiencia, reduciéndola, en efecto, al escenario concreto de la realidad sensible.

Sabemos que una de las principales consecuencias del positivismo es el intenso desarrollo a que se ven impulsadas las ciencias particulares, desarrollo que trae consigo el auge de la industria y en general, de todo lo que se ha denominado bajo el término progreso. Más tarde, Stuart Mill, discípulo de Comte, historia este progreso y lo define como una conquista de orden más o menos material, ajena en todo caso a los valores subjetivos.

Corresponde a esta etapa de la cultura la evolución sufrida por el concepto de moral. Sin entrar en la casuística ni en detalles más o menos pasajeros, nos vamos' a referir en general a la ética de Mr. G. E. Moore. La ética, según este pensador inglés, no es una ciencia que deba girar exclusivamente en torno al alma humana, sino que hay que ponerla también en las cosas, las cuales pueden ser buenas o malas, independientemente de nuestros juicios, del mismo modo que una cosa puede ser falsa o verdadera, con prescindencia de nuestra opinión personal.

Coincide con esta concepción objetivista de la moral, la actual noción de libertad, que ha evolucionado desde una acepción subjetiva y metafísica a un significado positivo, acorde con las necesidades de la vida social.

Hay que reconocer que hoy día el grupo humano, llámese gremio, sindicato, asociación o Estado, está adquiriendo una gran preponderancia sobre el individuo, el cual, considerado aisladamente, desaparece a fin de dar vida autónoma a la cor- 
poración. León Duguit, por su parte, ha proclamado la tesis del Derecho objetivo. Esta ciencia no se basa en un principio innato, de oriundez metafísica, como se sostenía desde los romanos, sino que es el producto liso y llano de la función social del individuo, del hecho de actuar en sociedad. Finalmente, el progreso de la Biología ha disipado la antigua magia del Espíritu. Ya el genio no tiene exquisiteces ni hieratismos que no hayan sido esclarecidos o interpretados a la luz de la Patología y de la Psicoanálisis.

Es de igual modo significativa para la interpretación plástica de nuestra cultura la actual resurrección de la fenomenología, escuela filosófica de raíz positivista, que es el tercero en discordia de la vieja disputa entre materialistas y espiritualistas. Es la fenomenología, según acertada definición de uno de sus apóstoles, una intelección de las formas de la objetividad. Esta manera de concebir el mundo, por las cosas en cuanto materia activa, ha influído todo orden de conocimientos, incluso el arte y la literatura. Las formas concretas tienen su representación metafísica en los arquetipos de las artes plásticas. De tal modo que una época en la cual predominan las formas concretas deberá estar regida estéticamente por los elementos de la plasticidad.

Tanto en poesía como en música, artes inmateriales por excelencia y de naturaleza auditiva, se ha entronizado una verdadera plasticidad, caracterizada, en la primera, por el alquitaramiento de la imagen-sucesión de rápidos cuadros de una emoción luminosa-y cuya total belleza resulta del arranque de la fantasía, que como un dios mitológico va engarzando los distantes productos imaginíferos; y en la música, por su tendencia no sólo a lo descriptivo, sino al refinamiento sensual (vale deciir visual), al mundo de las sonoridades coruscantes y bizarras.

La novela no se nutre ya en los espacios siderales de un psicologismo que culmina y talvez muere en Proust, sino en el ancho y exótico panorama de los viajes. Cosa no bien precisa de anécdotas; pero sí de dibujo y colorido. Con respecto a la pintura y demás artes plásticas, podemos decir que el motivo, en función de la primera, constituye uno de los tópicos más interesantes de la Historia del Arte. Pasados los primeros desvarios de un lógico movimiento de renovación, la plásica se va precisando en un terreno que tiene mucho de clásico. (Pero esta materia daría para un par de ensayos más. Bástenos decir por ahora que, en general, las artes plásticas, como familia artística favorita de la época, buscan su venero en lin- 
des propias, tienden a fundar un arte exclusivamente formalista y, por decirlo así, corpóreo.)

Todo esto revela en forma indiscutible la hegemonía de las cosas o por lo menos su yuxtaposición con los valores humanísticos, lo cual expresado en un lenguaje algo patético, significa la muerte del Romanticismo.

La forma, la forma concreta y tangible es la prueba máxima de toda existencia. Ella es el broche que cierra el círculo de lo creado; la revelación primaria y la última del conocimiento. Ahora bien, a una época de civilización, no de cultura, donde la creación espiritual es desmedrada, corresponde una producción material intensa. Sin embargo, no hay en estas écocas decadentes una efectiva ausencia anímica, sino solamente como una saturación y hastío del espíritu que le induce a comprobar lo ideado en épocas anteriores.

Un pensador eminentísimo ha sostenido, de acuerdo con lo que acabamos de exponer, que nuestra época corresponde aJ último eslabón del ciclo orgánico de una gran cultura. Esto quiere decir que somos testigos de un período de decadencia, de mera civilización, la cual vive, como una gran artista envejecida, pugnando por detener sobre su rostro la acción corrosiva del tiempo.

Repítese pues, el eterno fenómeno de la reacción del hombre frente a lo desconocido, que en los pueblos primitivos se manifiesta con carácter religioso y que no es sino una forma de conocimiento tendiente a conjurar el misterio de los fenómenos naturales y, en último grado, el miedo a la muerte. Pero el hombre contemporáneo como ya no puede crear lo que le daría una sensación de vida más intensa, esto es, las grandes obras de trascendencia espiritual, crea desesperadamente y con profusión, las cosas externas, dándoles con frecuencia magnitudes ciclópeas (1).

Ver. Desde niño la pasión del hombre es ver, y su primer alimento espiritual lo ingiere por la vista. Luego el niño crece y se encuentra ante dos perspectivas ignoradas. Lo distante que queda fuera del alcance de sus ojos y lo cercano que se oculta. Ofrécensele, entonces, como medios correlativos, el viaje y la mujer. La mujer, como hechizo de forma natural y de cosa prohibida y el viaje, como realización de la forma de lo desconocido.

(1) Relacionando estos conceptos nos encontramos frente a un postulado de cuya originalidad no estoy cierto: el instinto creador del hombre está intimamente ligado al sentimiento religioso. 
¡Acaso esta pasión de ver, doblemente simbolizada en la historia bíblica de la mujer de Loth, nos esté llevando nuevamente al término de las Ciudades Malditas! Y he ahí que cual una fruta reluciente y de sabor eternamente desconocido, el sexo, el Dios-Sexo, es adorado a plena luz como el signo magnífico de la imponderable necesidad de ver.- J os É $M$ ANUEL SÁ NCHEZ.

\section{París y el centenario del romanticismo}

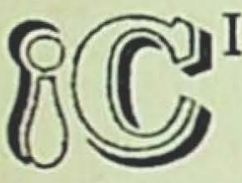

IEN años de romanticismo! Es bastante. París conmemora la historia de lo que ha sido su vida y su savia durante tan largo tiempo. Su bruma, sus flechas y sus aguas hablan hoy de ese "mal del siglo» que se representaba con un lago de fondo, un árbol inclinado y un joven meditabundo.

¿Qué es preciso entender por la palabra romanticismo? Un arte en que la imaginación y la sensibilidad predominan sobre toda otra facultad del espíritu, es la definición más acertada. En un sentido más vasto: vida adaptable «au roman». El romanticismo pasó como una avalancha invadiéndolo todo: música, literatura, política, poesía. Una revolución tan grande sólo la verán los siglos en el movimiento obrero que ha cambiado y cambiará las raíces mismas del hombre. Hoy existe en determinados medios y países una ideología marxista que invade el total de los campos espirituales y materiales. Ahí no se juzga a los artistas sino desde el punto de vista de clase: Proust, Gide, Paul Valéry son sólo los representantes de una burguesía ociosa y corrompida.

Esta cruz negra sobre el romanticismo y sus derivados, tomándolo en un sentido de exaltación del más allá, nos parece difícil concebirla. Hoy más que nunca el hombre busca la belleza abstracta, la combinación de imágenes y líneas que lleven a la irrealidad. El mundo ha dejado de ser una representación gráfica y se pretende fijar lo desconocido, la emoción de lo inexistente, la armonía de la desarmonía. Esfuerzos estériles de una sociedad en decadencia traducen los de mañana que miran al hombre que sufre, que lucha y que trabaja.

¿Esta tragedia del individualismo dará paso a un arte anónimo, como el gótico-religioso? Eso lo dirán y lo verán los si- 